\title{
Marginalizált térből átmeneti térbe Egy térbeli-társadalmi mobilitási pálya megélt jelentései ${ }^{1}$
}

\author{
Németh Krisztina \\ https://doi.org/10.51624/SzocSzemle.2020.2.3 \\ Beérkezés: 2020. 06. 05. \\ Átdolgozott változat beérkezése: 2020. 09. 30. \\ Elfogadás: 2020. 10. 20.
}

\begin{abstract}
Összefoglaló: A tanulmány egy stigmatizált és marginalizált falusi térből egy társadalmilag heterogénebb városi átmeneti térbe (Vigvári 2016; Virág 2018) költöző roma nő, illetve családja térbeli, valamint társadalmi mobilitásának ívét és megélt tartalmát próbálja elemezni a habitust „társadalmi helyérzetként” (Bourdieu 2002; Hillier-Rooksby 2002) értelmezve. Az elemzés a "társadalmi helyérzetként" felfogott habitus kognitív struktúráit a helyek reprezentációján, a helytapasztalaton, a testiesült struktúráit a térhasználaton és az életmódon keresztül vizsgálja (Bourdieu 2000, 2002; Dúll 2014, 2015a, b). Az elemzés megmutatta, hogy a szóban forgó család története nem egyszerủen egy falusi marginalizált térből egy relatíve jobb helyzetủ városi átmeneti térbe vezető térbeli mobilitás. Mind a térbeli, mind a társadalmi (foglalkozási) mobilitás fokozatos kiágyazódást és előrelépést mutat, amit egy mikromobilitás (Porcelli et al. 2014) indított el. A térbeli és a társadalmi mobilitás íve a helyek reprezentációjából és a foglalkozási mobilitással járó (társadalmi) szerepváltozásokból kiolvasható, míg a mobilitás megélt tartalmát, a habitusra gyakorolt komplex hatásait a térhasználat és az életmód változásai, illetve az ezek körüli feszültségek fedik fel. A térbeli mozgást a kibocsátó falusi tér taszító tényezői és a városi zsugorodás kontextusában alakuló sajátos átmeneti tér is alakította. Következésképp ez a mobilitási pálya egyszerre tekinthető bizonyos fokig tipikusnak az adott városi átmeneti térben, illetve atipikusnak a falusi marginalizált térből való ritka kilépés miatt. A család mindkét térben kissé „kilógó”, ambivalens pozíciót foglal(t) el, ami a térbeli-társadalmi mobilitással együtt ambivalens „társadalmi helyérzetet” körvonalaz. Az ambivalenciák, azaz a mobilitás megélt jelentései önértelmezésre, önpozicionalizálásra sarkallnak, ami betekintést nyújt a habitus lassú adaptálódásának folyamatába.
\end{abstract}

Kulcsszavak: térbeli és társadalmi mobilitás, habitus, társadalmi helyérzet, helyreprezentáció, térhasználat

1 A tanulmány a Nemzeti Kutatási Fejlesztési és Innovációs Alap „Marginalizáció és (im)mobilitás: a habitus dinamikája” (124455 számú) projektjéből biztosított támogatással, a posztdoktori (PD_17) pályázati program keretében készült. A terepmunka és a posztdoktori kutatás kapcsolódik a „Helyi közpolitikák és a marginalitás (újra)termelődése hanyatló városokban" (119465) címü, Virág Tünde által vezetett NKFIH-kutatáshoz.

Köszönöm a tematikus szám vendégszerkesztőinek és szerzőinek, valamint az anonim lektoroknak a kézirathoz füzött megjegyzéseket és kritikát. 


\section{Elméleti keretek: hely(tapasztalat), térhasználat, mobilitás, „társadalmi helyérzet”}

A fizikai tér, az épített és a mindennapokban bejárt, belakott környezet sokféleképpen hat az egyénre, és tartós nyomokat, beállítódásokat rögzít benne. A környezetpszichológia alapvetése, hogy a fizikai tér „szituálja” a viselkedést, miközben az ember és a környezete közötti kölcsönhatásokon keresztül válnak „szociofizikaivá” a terek (Dúll 2015a: 19). „A térbeliséget, a világ és az ember állandóan zajló »együttműködését «" (Hidas 2015: 38) a humán és társadalomtudományok igen sokrétűen tárgyalják (Berger 2018; Bourdieu 2000; Creswell 2009; Dúll 2014, 2015a, b; Hidas 2015; Keszei 2015; Kollár-Tamáska 2019). Mindezeket a kölcsönhatásokat a környezetpszichológia a helyélmény, a helytapasztalat, a tér-, avagy helyhasználat és a helyidentitás fogalmaival vizsgálja ${ }^{2}$. A „szociofizikai tér” gyakorlati cselekvésekkel (használaton vagy épp elkerülésen, mindennapi rutincselekvéseken, a „lakozáson” [Hidas 2015: 41] keresztül) vagy gondolati-affektív múveletekkel (kötődés, viszolygás, emlékezés, aszszociáció) válik „pszichológiai értelemben interpretált térré, azaz hellyé” (Dúll 2015a: 21). A fizikai tér tehát a jelentéseken és a jelentőségen keresztül válik hellyé (Creswell 2009). A helyélmény voltaképpen a fizikai tér megélt (értelmezett), affektusokkal átszőtt tapasztalata (Dúll 2014, 2015a, b; Keszei 2015). A hely reprezentációja stabil és előhívható tudás a helyről, egyfajta kognitív-mentális struktúra, amely a mindennapi gyakorlatokat rutinná szervezi (Dúll 2014, 2015a, b). A helyeknek mint jelentésekkel teli struktúráknak (Creswell 2009; Dúll 2014, 2015a, b) kitüntetett szerepe van az élettörténetekben (Keszei 2015). A helyekhez való viszonyulások, tapasztalatok az identitás alapelemei, amelyek az állandóság, a folytonosság, az érzelmi stabilitás és az odatartozás érzéseit nyújtják, egyben az adott térhez kötnek bizonyos típusos tapasztalatokat (Dúll 2015a, b; Hidas 2015; Keszei 2015).

Fenomenológiai értelemben a tapasztalat voltaképpen az ember és a világ viszonya (Creswell 2009). Bourdieu (2000) szerint a helyek közvetlenül hatnak az egyénre a testen keresztül, ami egyfajta „lenyomatként” (memory pad - Bourdieu 2000: 141) őrzi a térbeli-társadalmi világ struktúráit. A test a társadalmi világba vetett, miközben a társadalmi világ a testbe bevésődik (Bourdieu 2000: 150-153). A habitus a világban való múködés többé-kevésbé állandósult módja, egyszerre „strukturált” és strukturáló struktúra: az észlelés, a gondolkodás és a cselekvés egy meghatározott módja, amely dialektikus viszonyban áll az objektív struktúrákkal (Berger 2018: 142; Bourdieu 2000: 148-153, 2002: 31). Ugyanakkor a habitust jelentős mértékben építik kevésbé vagy egyáltalán nem tudatosult, „bevésett” tapasztalatok, következésképpen „csak abban a környezetben múködik problémamentesen, ahol elsajátítása korábban végbement" (Fáber 2018: 57).

2 A helyélmény épp az állandóságon, a bejósolhatóságon, a környezet felett érzett kontrollon keresztül nyújthat érzelmi stabilitást. Az odatartozás élménye, a helyhez való erős érzelmi viszony (helykötődés) időbeliséget is kölcsönöz a helyekhez való viszonynak, miközben a helyek tapasztalata tartósan beépülhet az egyén identitásába. A helyidentitás a személyes identitás egyik kitüntetett alstruktúrája, amely folytonosságot teremt, és olyan tartós sémákat alakít ki, amelyekkel az egyén képes felismerni, hogy mi lehetséges, milyen viselkedés megfelelő az adott helyen (egyén-környezet közötti illeszkedés) (Dúll 2014, 2015a, b). 
A habitus a társadalmi tapasztalatok inkorporációja miatt feltételezhetően „a téri gyakorlatokat is vezérli” (Berger 2018: 146). A habituson keresztül a világ „belülre kerül”, és épp ezáltal válik otthonossá (Bourdieu 2002: 143). A habitus közvetlenül is összefüggésbe hozható valamely társadalmi pozíció „belakásával”, elsajátításával, valamint az adott társadalmi pozícióhoz kötődő „otthonosság” érzésével (Berger 2018: 146). Következésképpen a habitus felfogható egyfajta „testiesült társadalmi helyérzetként" is (Hillier-Rooksby 2002: 5), ami ily módon az egyik legalapvetőbb, bensővé tett tapasztalatról, az egyén világban való helyéről és az ahhoz füződő kognitív és testiesült viszonyáról informál (Bourdieu 2002; Hillier-Rooksby 2002). A társadalmi helyérzetként felfogott habitus látni engedi a betöltött pozíció és a diszpozíciók, valamint a habitus és a belakott világ (habitat) összeillését vagy össze nem illését ${ }^{3}$, illetve a másokhoz, a más társadalmi pozíciókhoz való viszonyulást is (Bourdieu 2000: 148, 2002: 150-153.)

Miközben az élettörténeti kontinuitás megköveteli a különböző helyek gondolati összekötését, a térbeli-társadalmi mobilitás szorosan kötődik a „honnan hová?” kérdéshez, ami elkerülhetetlenül helyekhez kötődik, és helyeken keresztül is értelmeződik. Mind a helyek, mind az elmozdulás maga térbeli, társadalmi jelentéseket sűrít, és önértelmezésre is sarkall.

„A tér bármely helyének leírása olyan megértő ábrázolási kísérlet, melynek kitüntetett referenciális vonatkozása a megfigyelő szubjektum egzisztenciális státusza. Waldenfels szerint »a helyhez « való viszony értelmezése a szerző reflexív tudatosságának függvénye, amit tulajdonképpen egyetlen látszólag egyszerü, lényegében lezárhatatlan kérdés tematizál: hol vagyok." (Biczó 2018: 54)

Az alábbiakban egy marginalizált falusi térből egy városi átmeneti térbe (Vigvári 2016; Virág 2018) költöző roma nő térbeli és társadalmi mobilitásának ívét, valamint megélt jelentéseit próbálom megragadni a habitust „társadalmi helyérzetként” (Bourdieu 2002; Hillier-Rooksby 2002) értelmezve. A társadalmi helyérzetként felfogott habitus tudatosult tartalmait, kognitív struktúráit az élettörténetbeli helyek reprezentációján, a helytapasztalaton, míg a kevésbé tudatosult, testiesült tartalmait a térhasználat és az életmód változásain keresztül próbálom megragadni. Ehhez a térbeli mobilitás mellett támaszkodom a társadalmi mobilitás mint különféle társadalmi (vagy foglalkozási) pozíciók közötti tartós elmozdulás fogalmára, valamint a szubjektív mobilitás fogalmára, ami az elmozdulás (illetve mozdulatlanság) szubjektív érzetét, továbbá ennek egyéni értékelését firtatja (Andorka 1982; Hajdu-Huszár-Kristóf 2019; Huszár-Záhonyi 2018).

\section{Módszertan}

$\mathrm{Az}$ elemzés több ülésben felvett élet- és családtörténeti ${ }^{4}$ interjúkon alapul, amelyet Gyöngyivel, egy középkorú roma nővel készítettem 2017-18-ban. Gyöngyivel félig

3 A habitus és a belakott (társadalmi) világ a lakáson, lakozáson, lakberendezésen keresztül (Berger 2018) elméleti kapcsolódási pontot teremt a környezetpszichológia egyén-környezet közötti illeszkedés fogalmával.

4 A családtagokkal készült interjúkat nem vonom be ebbe az elemzésbe. 
strukturált interjúkat készítettem, amelyekben a családtörténeti összefüggéseken túl nagy hangsúlyt fektettem a terek és a hozzájuk kapcsolódó emlékek, érzések és gyakorlatok felidézésére ${ }^{5}$. Az elemzésben arra koncentrálok, hogy miként olvashatók ki a különféle (marginalizált) helyek reprezentációjának és a hozzájuk kötődő praxisoknak a változásaiból a mobilitási pálya „objektív” és szubjektív jelentései, valamint hogy a megélt és inkorporálódott helytapasztalatok hogyan formálódnak egyfajta „(testiesült) társadalmi helyérzetté" (Hillier-Rooksby 2002: 5), és miként járulhatnak hozzá az önértelmezéshez. A térbeli-társadalmi elmozdulást ugyanakkor nem csak a narratív önértelmezésen, hanem a (z elbeszélt) gyakorlatokon, a habitusban rögzült reagálási módokon, illetve ezek változásain (Bourdieu 2000, 2002; Hillier-Rooksby 2002) keresztül is vizsgálat tárgyává teszem. Ily módon az interjúhelyzetbeli énbemutatást (Goffman 1981) megpróbálom kitágítani a gyakorlatok felé is azzal, hogy átjárást keresek az elbeszélés és a praxis között (Kovács 2006: 41). A habitust építő tudatosult tartalmak és összefüggések könnyebben reprezentálódnak a narratív identitásként felfogható élettörténeti szövegben ${ }^{6}$ (Keszei 2015; Kovács 2006, 2007a, b; Kovács-Vajda 2002). A nehezebben elbeszélhető, azaz kevésbé tudatosult, például testiesült tartalmakról ${ }^{7}$ viszont inkább a gyakorlatok és a feszültségek, az ambivalenciák tudósítanak.

$\mathrm{Az}$ elemzésbe háttérként, kontextusként bevonok más, a téma szempontjából releváns terepi interjúkat, valamint más kutatások eredményeit is, amelyeket igyekszem a saját eredményeimmel összevetni, összekötni.

\section{A városi tér és a kontextus: egy zsugorodó iparváros átmeneti tere}

Kutatásunk egyik terepe egy olyan városi tér, amelynek története, helyzete és reprezentációja szorosan kötődik a szocialista nagyipar fellendüléséhez és hanyatlásához. Különösen igaz ez a kiválasztott mikrotérre. Ez a város legfiatalabb városrésze, egy valamikor magas presztízsưnek szánt szocialista lakótelep, amely önmagában is erős szimbolikus jelentéssel bír mint a szocialista modernizáció és életforma építészeti lenyomata és ígérete ${ }^{8}$. A szóban forgó lakótelep a várostól térben is kissé elkülönül, miként egy ott felnőtt szociális munkás fogalmazott: „a semmi közepén” áll. A várostól való távolsága relatív marginalizáltságának egyik jele és oka. A másik, ennél fontosabb tényező a nagyberuházás befejezetlensége, ami főként a lakótelep infrastrukturális hiányosságaiban, a helyi intézmények részleges hiányában, az utak és a lakóépületek relatív elavultságában megfogható. A tér befejezetlensége őrzi a '80-as évek gazdasági válságának városi környezetbe írt hatását, amelyet a rendszerváltás (később a gyárbezárások) és a zsugorodás (elvándorlás) is súlyosbítottak (Czirfusz et al. 2019;

5 Bár az interjúfelvételetek nem követték a narratív életútinterjú kötött kérdezéstechnikáját (Kovács 2007a, b; Kovács-Vajda 2002), a narratív kérdések részleges alkalmazása teret engedett az önálló, asszociációk által vezetett mesélésnek. Bár nem végeztem el az egyéni (hermeneutikai) esetrekonstrukciót, az elemzés során erősen támaszkodtam ennek módszertani fogásaira (finomelemzés, abdukció; lásd: Kovács 2007b; Kovács-Vajda 2002; Shank 2008).

6 Ugyanakkor ez nem jelenti feltétlenül azt, hogy a tudattalan vagy nehezebben verbalizálható tartalmak, össze nem illeszkedések, homályos érzetek ne formálnák a narratív, avagy a személyes identitást. A narratív identitás és a tudattalan identitás kapcsolatáról lásd: Pintér 2012.

7 A testbe írt társadalmi tapasztalatokról és a tudatosság kérdéséről lásd bővebben: Fáber 2018.

8 Más városi térben és egy speciális kontextusban lásd erröl N. Kovács Tímea (2019) elemzését. 
Jelinek 2020). A lakótelep befejezetlenségéhez így társadalmi problémák is kapcsolódtak, mindenekelőtt az ott lakók (rokkant)nyugdíjazása, illetve munkanélkülisége, miközben a megélhetési gondokat a korszerűtlen és pazarló fütés, valamint az épületek rossz hőszigetelése miatti tetemes rezsiköltség is tetézte.

Ma a szóban forgó lakótelepen a megkérdezettek szerint a városi átlagnál olcsóbbak az ingatlanok. A sajátos ambivalenciák miatt a lakótelep inkább egyfajta átmeneti tér, amely társadalmilag viszonylag heterogén és nem (vagy csak enyhén) stigmatizált (vö. Vigvári 2016; Virág 2018). Élnek itt a régi nagyiparhoz kötődő stabilabb helyzetű családok, nyugdíjasok, akik ki tudják gazdálkodni a rezsit. Mellettük a viszonylag olcsó ingatlanok heterogén, jellemzően az alsó és az alsó középosztályi lét peremén billegő családokat vonzanak ide: fizetésképtelen, más városi terekből kihulló devizahiteleseket, kevés tőkével vagy tőkével nem rendelkező, megkapaszkodni vágyó fiatal párokat, kisgyerekeseket, valamint más, marginalizáltabb terekből menekülő, munka és otthon után vágyó kisegzisztenciákat (mint Gyöngyi és családja). Esetükben a tetemes rezsiköltség a lakáshitelekkel együtt könnyen adósságcsapdává válhat (Csizmady-Hegedüs-Vonnák 2019). Nem véletlen, hogy a szociális szakemberek látóterében is megjelenik a városrész, amelyet egyikük így jellemzett: „a gyökértelen, sikertelen életet maguk mögött tudó családoknak a mentsvára."

A szociális szakemberek szerint a szóban forgó lakótelep egy időben „szellemváros” volt az üres lakások miatt. Bár a kifejezés elterjedtsége és organikus volta önmagában is felvet kérdéseket, az elnevezés mindenképp rögzíti a város hanyatlását. Ebben az elvándorlás és a külföldi munkavállalás is megjelenik a városi térre, különösen a városrészre vetítve. A lakótelep vonzó és taszító tényezői együttesen magyarázzák a fluktuációt: a kimenekülést avagy előrelépést ebből a térből, és az új belépők érkezését.

A városrész ma ellentmondásos mutatókkal jellemezhető; atipikus a zsugorodó iparvároson belül is. A korösszetétele fiatalos, és nem mutatja a szegregálódás jeleit ${ }^{10}$ (Koós 2020; Virág 2020), ezzel együtt mégis elég ambivalens helyzetû a városban. Egyes vélemények szerint „gettó”. Az erős kifejezésben megjelenik a lakóhelyi vagy területi stigmatizáció (territorial stigmatization) (Wacquant 2011; Wacquant-SlaterPereira 2014) lehetősége, ám ez inkább azzal az önkormányzati szándékkal hozható összefüggésbe, hogy az a lakótelep szegregátummá nyilvánításával allokáljon ide fejlesztési forrásokat. A benne élők jó része azonban nem látja kirívónak a városrész helyzetét. A szóban forgó lakótelep városon belüli pozícióját például egy ott felnőtt szociális munkás a „kicsit mostoha” fordulattal írta le, amellyel arra utalt, hogy erre nem költenek annyit, mint más lakótelepekre. Más szociális szakemberek azonban

9 A szellemváros kifejezést a szociális szakmában dolgozó interjúalanyok önmaguktól csak ritkán használták, de mások is ismerték és ide kötötték a kifejezést, ami arra utal, hogy valamiképp része a városrészről alkotott diskurzusnak. Ugyanakkor a kifejezés többnyire rákérdezésre került elő, ami jelzi, hogy nem túl bevett vagy elterjedt vélekedésről van szó. Az egyik szociális munkás a kifejezés felbukkanását egy videoriporthoz kötötte, ami megmagyarázza a relatív ismertséget, ugyanakkor fokozott óvatosságra is int e toposz értelmezésekor (lásd még erről e számban: Virág 2020).

10 A számítás 2011-es adatokra épül, és az aktív korúak (15-64 évesek) körében a legfeljebb általános iskolát végzettek és a nem foglalkoztatottak (azaz a munkanélküliek és az inaktívak) arányát veszi alapul. A módszertanról és a kutatás kontextusáról lásd bővebben: Koós 2020. 
a jövőben egy potenciális városi problémagócként is el tudják képzelni. A megítélése tehát ambivalens; a percepciója azonban nem pusztán a fizikai tértől és annak paramétereitől függ, hanem az ott élők társadalmi helyzetétől, sorsától is ${ }^{11}$. Bár erről nincs kvantitatív adatunk, a lakosságcsere a lakók és a szociális szakemberek véleménye szerint inkább az utóbbi tíz évben vált látványosabbá, ami bizonytalanabbá tette a szóban forgó lakótelep jelenbeli és jövőbeli pozícióját a városban. Ezt a billegő, relatíve marginalizált, relatíve normalizált megítélést mi sem jelzi jobban, mint hogy a megkérdezett, jobbára alsó középosztályhoz sorolható szociális szakemberek közül többen is kötődnek ehhez térhez; ott élnek vagy ott nőttek fel. Mindez olyan benyomást kelt, mintha az ambivalens, enyhén stigmatizált városrész megítélése is átmeneti lenne a városi diskurzusban, amit a stabilitásra vágyó egzisztenciák jelenléte is visszatükröz. Ezek fényében nem is olyan meglepő, hogy itt találkoztam az idősgondozóként dolgozó Gyöngyivel, aki egy falusi, erősen marginalizált teret elhagyva itt próbál a családjával megkapaszkodni és egzisztenciát teremteni.

\section{Élet-és családtörténeti váz}

Az 1976-os születésű, roma származású Gyöngyi anyja és apja is az 1940-es évek elején született. Gyöngyinek hét testvére volt. Édesapja a nyugdíjazásáig a közeli nagyobb városban dolgozott építőipari segédmunkásként, anyja háztartásbeli volt. Gyöngyi kisiskolás volt, amikor az anyja meghalt. Ezután az apja a legkisebb gyerekeket, köztük Gyöngyit, egyedül nevelte. Az ő nyugdíjából és a még otthon élő nagyobb testvér pénzéből éltek. Az apa közel húsz éve halt meg.

A család egy faluban élt, pontosabban a falutól térben és társadalmilag elkülönülő, erősen izolált és stigmatizált helyen, egy komfort nélküli, egyhelyiséges önkormányzati bérlakásokból álló soron („cigánysoron”) ${ }^{12}$. Gyöngyi helyben végezte az általános iskolát, a falu egyetlen általános iskolájában, majd egy közeli városban tanult szakmát, de hamar abbahagyta az iskolát. Előbb rövid ideig egy nagyobb városban dolgozott egy hűtőházban, majd a faluban egy szövőgyárban helyezkedett el, de időközben volt közfoglalkoztatott és munkanélküli is.

Közel húszévesen ismerte meg a szintén falubeli, de nem a marginalizált térben lakó roma férjét, majd a férfi hozzájuk költözött. Később a fiatal pár egy másik komfort nélküli lakásba költözött ugyanazon az önkormányzati házsoron. 2006-ban gyerekük született. A férfi évekig a szakmájában dolgozott szakácsként egy nagyobb városban, majd később különféle üzemekben szinte folyamatosan dolgozott betanított munkásként. 2007-ben a család a szóban forgó lakótelepre költözött. A kétszobás panellakáshoz az önerőt szociálpolitikai támogatás jelentette, a vételár nagy részét hosszútávra felvett devizahitelből fedezik. A 2008-as válságot követően alig tudták törleszteni a lakáshitelt, egy ideig a lakásuk is veszélyben forgott.

11 „Egy kerület és egy város (minden kerület és minden város) elsősorban is sorsokból áll” (A. Gergely 2007: 7).

12 Mivel Gyöngyi történetéből úgy tünik, hogy ez az elnevezés az elemzett marginalizált mikrotér "bevett” falubeli neve, ezért az elemzéshez én is használom, hogy érzékeltessem a falun belüli helyzetét, stigmatizáltságát. 
Gyöngyi a költözés után gondozói képesítést szerzett. Több mint tíz éve idősgondozóként dolgozik közalkalmazotti státuszban a város egyik intézményében. A férje egy közeli városban helyezkedett el egy közepes méretű cégnél. A család megélhetése alacsony státuszú bérmunkán alapul, bevételeiket lakás- és létfenntartásra (rezsire, lakáshitelre, a munkába járás költségeire és élelmiszerre) fordítják. A gyerekük a jobb státuszú tanulókat vonzó, szomszédos lakótelepi iskolába jár, a terepmunka idején pályaválasztás előtt állt.

\section{A térbeli mobilitás íve: a helyek reprezentációja és a hely- tapasztalatok}

\section{A marginalizált falusi tér és a hozzá kötődő jelentések}

A megtett térbeli és társadalmi utat az első interjú legelső gondolata sűríti, amely a gyerekkort firtató kérdésre felelt. Gyöngyi a gyerekkorának elmagyarázásához, kontextusba helyezéséhez rögtön a mostani pozíciójába „kapaszkodik”. Mintha a múlt és jelen között feszülő élettörténeti ív a „honnan hova?” kérdésen, azaz a helyek közötti mozgáson keresztül válna megragadhatóvá. Eközben a térbeli mobilitás ténye rögtön éles megvilágításba helyezi a mobilitás szubjektív jelentőségét és az anyagi nehézségeket:

„Hát, a gyerekkor... igazából öhm, hát mi körülbelül tíz éve lakunk itt, tehát én [a faluban] laktam. Egész kisgyerekkorom, hát ott, ott, hát, itt születtem [a szóban forgó városban], de ott laktunk a szüleimmel [a faluban], és hát körülbelül tíz éve lakunk itt, ide költöztünk, lakáshitel-vásárlás volt, és akkor úgy tudtunk ideköltözni."

A válasz ugyanakkor a gyerekkorra irányuló figyelmet is igyekszik tompítani, amelynek helyszíne, mint később kiderül, egy stigmatizált falusi tér. Jóllehet Gyöngyi egész gyerek- és fiatalkorát itt töltötte, ennek ellenére csak fokozatosan és némiképp ellentmondásosan bomlik ki a falu és a falutól távolabb eső, marginalizált házsor viszonya. Gyöngyi ezt csak egy későbbi találkozáskor nevezi vonakodva a falusiak által használt nevén „cigánysornak”.

„...ahol mi laktunk, hát, hogy mondjam, mondjam csúnyán?, nem lenézésböl, és sose nem felejtem el, hogy honnét [származom]: cigánysor. Most mondjam úgy? Most tényleg el volt szegregálva a falutól, egy külön, elszigetelt öhmm helyen laktunk, és egy sor. [...] Oda raktak minket, most csúnyán kifejezve, hogy tényleg oda csaptak minket, hogy "jó lesz ott nektek«, gondolván; és egy kicsit még arrébb laktak ilyen rossz vérü cigányok, most ühhmm olyanok, na. Most nem az, én is az vagyok, csak mégis másabb. [sóhajt]”

Voltaképpen ez az egyetlen nyíltan szóvá tett negatívum, amit a falujáról mond, miközben az elbeszélésében azt hangsúlyozza, hogy kötődött a faluhoz, legfőképp a gyerekkori otthonához, még akkor is, ha az a falun „belül” stigmatizált volt. Az otthonhoz ugyanis jó családi és közösségi emlékek is kötik, miközben ugyanehhez a térhez félelem is kapcsolódik a másik telepi roma családok zaklatásai, fenyegetései miatt. Még a félelemnél is nehezebb volt talán Gyöngyinek a cigánysoron megélt szegénységről, az egy 
helyiségből álló kis lakásról, a zsúfoltságról mesélnie. A gyerekkori történeteiből lassan bomlik ki a falutól távol eső házsor marginalizáltsága, lakóhelyi (területi) megbélyegzettsége (Wacquant 2011; Wacquant-Slater-Pereira 2014), amely megmutatja, hogyan válnak a térbeli hátrányok (a fizikai távolság miatti korán kelés, a sáros, latyakos utakon való gyaloglás) a szegénység és az etnikai származás közvetítésével társadalmi hátrányokká, azaz hogyan társulnak ezekhez negatív társadalmi jelentések a faluban.

Az elbeszélésből úgy tűnik, hogy a lakóhelyéhez kötött stigmatizált jelentéstartalmakat Gyöngyi gyerekkorában elsősorban az iskola közvetítette. Az iskola az a hely, ahol saját maga („hogy ki vagyok, mi vagyok”) és az otthonának megbélyegzettsége problematizálódott. Gyöngyi nem szeretett iskolába járni, ahol származása s talán szegénysége miatt csúfolták. Csak akkor érezte biztonságban magát, ha a nővére is vele volt. Ugyanakkor a családtörténetben az iskola és tágabban a falu volt a vitathatatlan igazodási pont, aminek meg kellett felelni, ahol újra és újra be kellett bizonyítani a kifogástalan tiszta ruhával, a szülők fáradhatatlan munkájával, hogy a stigma rájuk nem vonatkozik, nem vonatkozhat. „[Anyám,] ahogy lehetett, tehát, tisztán és szépen öltöztetett. Tényleg nagyon figyelt ránk."

A „cigánysor” stigmatizált (helyi) jelentései és ezek (részleges, felemás) elutasítása közötti ellentét beépült Gyöngyi habitusába, sokáig szégyent (Wacquant-SlaterPereira 2014) és érzelmi nehézségeket okozott neki ${ }^{13}$. Az etnicitással gyakran egybecsúszó területi stigmatizáció elleni védekezés egyik módja a stigma másokra való áthárítása (Goffman 1981), amelyet Wacquant „oldalirányú befeketítésnek” (later denigration) nevez (Wacquant 2011: 12). Gyöngyi történetében mindvégig hangsúlyos az a küzdelem, ahogyan gyerekkorában próbálta magától távolítani a származását a falusi térben. Bár ott a területi és etnikai stigma jószerével elháríthatatlan volt, a viselkedésével igyekezett magát és családját megkülönböztetni a másik, veszélyes roma családoktól: „én is az vagyok, csak mégis másabb”.

\section{Út a városi lakótelepre}

Megismerkedésük után Gyöngyi férje Gyöngyi családjához költözött a marginalizált házsorra. Kevéssel ez után megfogalmazódott bennük az önállósodás igénye. A térbeli mobilitásukat egy egészen kisléptékú, szinte láthatatlan és látszólag jelentéktelen mikromobilitás ${ }^{14}$ indítja el, amikor a fiatal pár különköltözik Gyöngyi családjától egy önálló önkormányzati bérlakásba. Jóllehet ez mindössze néhány ajtónyi távolságot jelent ugyanazon a házsoron, mégis fordulópontnak tűnik, ugyanis mind az értékek-

13 Az etnicitás és az önazonosság kérdése átszövi Gyöngyi élet- és mobilitástörténetét: az ehhez való viszonyulás dinamikája egyfelöl megmutatkozik a marginalizált terek reprezentációi körüli ambivalenciákban, valamint a foglalkozási mobilitással összefüggésben a térhasználat és a szereplehetőségek változásában. Mindezek komplex módon hatnak az énképre, csakúgy, mint az életmódváltás, az orientációk változása. Ugyanakkor ezen összefüggések etnicitás felőli értelmezése túlmutat e tanulmány keretein.

14 A mikromobilitást a kisebb léptékű, sokszor kívülről láthatatlan térbeli mozgások megragadására használom (lásd a lakásmobilitás kontextusában: Németh 2020), kiterjesztve a kifejezés Porcelli és szerzőtársai (2014) által használt jelentését, akik fogyatékkal élő fiatalok napi útvonalai, tevékenységei vizsgálatára használták a fogalmat, és ebben a mozgástér bővítésének eszközét, azaz a társadalmi egyenlőtlenségek csökkentésének lehetőségét látták. 
ben, mind az orientációkban jelentős változást hoz. Ezt az is alátámasztja, hogy a különköltözést gyorsan a lakásvásárlás és a városba költözés követi.

„És akkor már azon gondolkodtunk, hogy különmenjünk, és akkor mindig csak egy kicsit mentünk külön, akkor öhm, tehát az apukám lakott a sorháznak az egyik végébe, mi meg átköltöztünk a másik végébe, de önálló élet, tehát külön voltunk. Ez már nekünk egy oltári nagy szó, hogy megmozdultunk, hogy egy kicsit különmentünk, hogy mondjam, a családtól, vagy nem tudom. Tehát nem az volt, hogy öhm, hogy van, akitöl függünk. Tehát minden téren. Hogy én most mikor tévézek, vagy mikor kapcsolom be, tehát hogy nincs ilyen, és akkor ez jó volt. [sóhajt] És hát nem nagyon sokáig voltunk ott, és akkor intéztük ezt a [városi lakást]. Itt meg ez [a szóban forgó lakótelep], ez valami álom."

A fenti mikromobilitás voltaképpen nemcsak a szülői családról való leválást (Gyöngyi szavaival a magánélet igényét) jelenti, hanem elindított egy fokozatos (előbb kognitív-mentális, majd fizikai) kiágyazódást is a marginalizált térből és a teret átszövő családi, rokoni hálóból15. A különköltözés elmélyítette az önállóság, a saját élet feletti döntés élményét, és ez fokozatosan újraírta a családi határokat is: a kétkeresős bérmunka felé orientálódó nukleáris család lassanként a kezébe vette a sorsát. Ezt új stratégiák és orientációk megjelenése is jelzi. A családalapítás és az otthonteremtés közepette a marginalizált tér percepciója is megváltozott legfőképp a zaklatások, a fenyegetések, valamint a „cigánysor” falubeli megítélése miatt. Ugyanakkor a kimozdulás esélyei is átértelmeződtek. Ebben a mikromobilitásban sűrűsödik tehát az orientációk változása, így nem meglepő, hogy a különköltözés a gyerekvállalással együtt - ugyanakkor nem csak amiatt - szinte rögtön továbblépésre késztet. A továbblépés terve ugyanakkor még az ismert, családi, rokoni támogatással átszőtt közegben született meg, ahol még nem kellett felvállalniuk a közeg elhagyásával járó nehézségeket. A különköltözés mindazonáltal az önállósodás és a térbeli mobilitás katalizátora és a családtörténetet építő ambíciók (és ambivalenciák) gyújtópontja.

Miközben a marginalizált térhez kötődő megtartó erők is megjelentek a történetben, a fiatal pár ekkor szembesült azzal, hogy a faluban nem tudnak a helyzetükön érdemben változtatni. Jóllehet a marginalizált házsoron kaptak egy lakást, máshol nem jutottak önkormányzati bérlakáshoz a faluban, holott érdeklődtek és pályáztak. A városba költözés előtt megnéztek helyben egy házat, de az túl drága volt nekik, és az állapota sem volt megfelelő. A mikromobilitás azonban feltehetően már lendületet adott az önállósodáshoz a fiataloknak, akik mindenképpen ki akartak jutni a cigánysorról egyfelől a félelem, másfelől a marginalizáció, a szegénység és az etnikai származáshoz tapadó stigma elől menekülve. Eközben szembesültek azzal, hogy a faluba nem (vagy legalábbis a tervezettnél sokkal lassabban) tudnak beköltözni. Mindez azt sejteti, hogy jelentős erőfeszítések kellettek ahhoz, hogy valaki abban a faluban romaként érvényesüljön, vagy a stigmatizált mikrotérből kikerüljön. Azonban fontos figyelembe venni, hogy Gyöngyi egyik testvére is bent él a faluban, és Gyöngyi elbeszé-

15 A családi, rokonsági kapcsolatok és hálózatok migrációs döntésekben betöltött szerepéről ld. Durst-Nyírő 2018a; Virág 2019. 
lésében a falu alapvetően jó helyként szerepel, ahonnan nem feltétlenül jöttek volna el, ha megfelelőek lettek volna a lakáskörülmények, vagy segítséget kapnak ahhoz, hogy beljebb költözzenek. Összességében a marginalizált tér hátrányai és a falubeli előrejutás nehézségei továbblökték őket a városi lakótelep felé, ahol egzisztenciájukat a saját erejükből, hitelre alapozva építették fel.

\section{A városi átmeneti tér ambivalenciái}

A városi lakótelepi lakást Gyöngyi férje találta egy lakáshirdetésben, és az első látásra megtetszett nekik. Ugyanakkor fontos korlátot jelentett, hogy anyagilag ez a lakótelep tűnt számukra elérhetőnek. A lakás reprezentációját Gyöngyi történetében erős pozitív jelentések szervezik, amelyek rögtön kontrasztot teremtenek a falusi marginalizált térrel.

„[A «cigánysoron»] nem jó volt, sírtunk, féltünk [sóhajt] kimenni az utcára is, mert ha láttak, akkor rögtön bántottak minket, és ez így, nekem ez így nem volt jó. De itt most, itt teljesen nyugalom van. Olyan jó. Ha hazajövök, senki nem piszkál. Elvagyok én úgy mindenkivel egy szintig, köszönünk és egypár szót váltunk, és vége."

A lakótelepi lakás a nagy erőfeszítések árán megszerzett otthon, ami lehetőséget nyújt a „normális” életvitelre. Ebben benne van a nyugalom a korábban tapasztalt zaklatásokkal szemben, a komfortos lakás kényelme a komfort nélküli egyhelyiségessel szemben, a városi térben kisebbeknek érzékelt távolságok (gyaloglás helyett busz), a magánélet újraírt határai (a nagyobb családról és a szomszédságról való leválás), valamint a társadalom többsége számára elérhető életmód képzete. Ez utóbbi ebben az esetben egy háromfős nukleáris család kétkeresős, alacsony státuszú, bérmunkával fenntartott városi (lakótelepi) létét jelenti (vö. Kovai 2019) ${ }^{16}$. Mindez Gyöngyi gyerekkorában legfeljebb álom lehetett, vagy még az sem.

„[M]ég álmomban sem [gondoltam], hogy én, én itt fogok lakni, és most nem is gondolnám azt, hogy... soha nem is gondoltam, hogy... Annyira jó nekem itt, hogy nem is kívánkozok oda vissza [a faluba]. Nem azért, merthogy [a faluval] problémám van, semmi, csak a kettőt összehasonlítva, így minden téren nekem itt [jobb]."

A gyerekfejjel elérhetetlennek tetsző otthon jól jelzi a falusi „cigánysorhoz” kötődő, gyerekként érzékelt mobilitási esélyeket (vö. Kende-Illés 2011). Az évtizedekre felvett devizahitel, amivel a lakást megszerezték, ugyanakkor folyamatosan komoly anyagi nehézségeket ró a családra. Volt, hogy fizetési halasztást kellett kérniük, mert nem bírtak a megnövekedett törlesztőrészlettel, amit egy keresetből próbáltak fedezni, mialatt Gyöngyi GYES-en volt.

Az alapvetően pozitív helyreprezentációt a megszerzett otthon, a kényelem és a biztonság mellett a lakótelepi térhez kötődő külsődleges jelentések (a városi hanyatlás toposzai) és a helytapasztalatok is alakítják. Jóllehet ma Gyöngyi ott lakóként és idősgondozóként nem lát különösebb eltérést a szóban forgó lakótelep és más város-

16 Kovai Cecília (2019) elemzésében a „normális életet” a rendszeres bérmunkára alapozott megélhetés, a nukleáris család és az otthonokba visszahúzódott élet jelenti egy másik, stigmatizáltabb városrészben élők szemében. 
részek között, mondandójában megjelennek kisebb ambivalenciák, amelyek árnyalják az otthonról alkotott teljesen pozitív képet. Azért, hogy ez utóbbit fenn tudja tartani, Gyöngyi esetenként elhatárolja az otthont a lakótelepi tértől, és a zavaró jelenségeket tudatosan kizárja a látóteréből.

„[...] vandálkodni, meg nem tudom, én ezeket így nem szeretem, az ilyet. Vannak itt olyanok is, de mi azokkal nem törödünk. [...] [Vannak,] akik ilyen kis lébecek, hogy nem dolgoznak, egész nap az utcán, meg vannak fiatalok [...] meg hát idösek is [...], megvan a kis nyugdija, elmegy, reggeltól estig ott van a kocsmában, ott van. Aztán az árokban fekszik. De az úgy engem nem foglalkoztat."

A magas rezsiköltségek és az ebből fakadó fluktuáció azonban felerősítik az amúgy is meglévő egzisztenciális bizonytalanságokat, szorongásokat, amelyeket viszont már nem lehet elválasztani a biztonságot nyújtó otthontól.

„Mert vannak, akik elmennek, mert nem tudják valamilyen oknál fogva fizetni a rezsit. Most szerintem mi is így lennénk, ha nem volna munkahelyünk, vagy az egyikünké megszünne, szerintem mi is nagyon rossz helyzetben lennénk, hogy, hogy tényleg, attól kéne félnünk, hogy nem tudjuk fizetni a lakáshitelt, meg a rezsit, meg mindent. [sóhajt] Úgyhogy jó, mondjuk nem egyszerü, de addig jó, míg van munkánk."

$\mathrm{Az}$ otthon reprezentációját ugyanakkor a lakótelepi térhez kötődő ambivalenciák és a zsugorodó város, a „szellemváros” toposzai nem igazán alakítják. Gyöngyi tisztában van ezekkel, azaz az elbeszélésében felvillannak az átmeneti térhez kötődő esetleges társadalmi problémák. Miközben a mindennapi tapasztalatok a „lébecekről” és az italozókról megkövetelik a tudatos kizárást, a szellemvároshoz kötődő társadalmi problémák Gyöngyit nem érintik; így ezeket könnyen elhalványítja a pozitív helykötődés, amely a lakásról esetenként a városi tér egészére is kiterjed: „[...] bárhonnét, ha hazajövök, én ide jövök haza. És ez nekem tetszik, meg én szeretem [a szóban forgó várost]. Sokan úgy vannak vele, hogy jaj [...], ha meghallják vagy meglátják [...], de nem, nem. Énszerintem, az én véleményem az [a városról], hogy egy nagyon jó város, én szeretek itt lakni. És a családom is."

Gyöngyi történetében tehát az enyhe marginalizáltsággal, relatív társadalmi hátrányokkal leírható városi átmeneti tér az ambivalenciái ellenére is erősen pozitívan reprezentálódik legfőképp az otthonhoz való pozitív kötődés és a jobb életfeltételek miatt. A hitelre vásárolt lakás - fenntartásának és megtartásának minden nehézsége ellenére is - a társadalmi felemelkedést és beilleszkedést, azaz a „normális” életet (vö. Kovai 2019) ígérő otthon meghitt tere. A szóban forgó lakótelepen éppen azért találhatott otthonra a család, mert ezt a városi zsugorodás ambivalenciái (mindenekelőtt a lakótelep befejezetlensége, a magas rezsiköltség és az ebből következő relatíve olcsó ingatlanok) lehetővé tették. A zsugorodás gazdasági és társadalmi következményei ugyanis egy olyan átmeneti teret eredményeztek, ami viszonylagos nyitottságával a megkapaszkodás lehetőségét kínálta a marginalizáltabb terekből, élethelyzetekből érkezőknek (vö. Vigvári 2016; Virág 2018). 


\section{Foglalkoztatási mobilitás - táguló terek és szereplehetőségek}

Gyöngyi történetében a „honnan hová?” kérdése egyfelől nagyon is konkrét helyekhez kötődik, másfelől társadalmi pozíciókhoz kötve is értelmezhető. Az általános iskola után Gyöngyi a közeli városba ment továbbtanulni, de hamarosan abbahagyta az iskolát, amit utólag megbánt. Ezután a faluból előbb munkásbusszal járt dolgozni egy nagyobb város hütőházába, majd egy tanfolyam elvégzése után a helyi szövőgyárban helyezkedett el, hogy anyagilag segíteni tudja az apját és a még otthon élő testvéreit. Időközben volt munkanélküli és közfoglalkoztatott is. („Én is dolgoztam az utcán.”) Röviddel a városba költözés után gondozói végzettséget szerzett, máig ezen a területen dolgozik közalkalmazottként. Mindez foglalkozási mobilitásként is leírható, mind intergenerációs (Gyöngyi 14 éves korában az apja már rokkantnyugdíjas, előtte építőipari segédmunkásként dolgozott), mind intragenerációs metszetben (araszolás a betanított munkás pozíciójából egy végzettséget igénylő munkakörbe).

A foglalkozási mobilitás ívéből hasonló fokozatosság olvasható ki, mint a térbeli mobilitáséból. ${ }^{17} \mathrm{~A}$ foglalkozási mobilitás ívét inkább kisebb, fokozatos előrelépések építik, amelyek együtt járnak a falubeli marginalizált térből való kiágyazódással. A foglalkozási mobilitás 18 évesen a betanított szalagmunkával veszi kezdetét, aminek a hútőház bezárása vet véget. Gyöngyi nagyon szerette ezt a munkát, kitűnt szorgalmával. Ezután egy hosszabb, stabil munkaviszony következett a falusi szövőgyárban a gyerekvállalásig. Ezt a munkát viszont Gyöngyi nem szerette és kimondottan kényszerből vállalta. Úgy tûnik azonban, hogy mindkét bérmunkaviszony alakította mind a térbeli, mind a társadalmi mobilitást. A kétkeresős önálló háztartás stabilizálása (illetve ennek vágya) ugyanis nagyjából egybeesik a Gyöngyi családjától való különköltözéssel, azaz az orientációk megváltozásával ${ }^{18}$ és a mobilitási vágyak erősödésével.

A térbeli mobilitás a falusi marginalizált térből a zsugorodó iparváros lakótelepére tehát nem pusztán szubjektíve jelentős (vö. Huszár-Záhonyi 2018), hanem társadalmi előrelépésként (foglalkozási mobilitásként) is értelmezhető. A térbeli mobilitás társadalmi aspektusai, megélt jelentései megmutatkoznak az életmódváltozásban, ami leginkább a térhasználat változásán, az orientációk és az életmód átalakulásában megragadható. Ennek habitusra gyakorolt sokrétú hatásai a „társadalmi helyérzet” (HillierRooksby 2002) ambivalenciáin és az önpozicionalizáláson keresztül elemezhetők.

\section{A térhasználat változásai - a térbeli és a társadalmi mobilitás megélt jelentései}

Az elhagyott falusi teret limitált és szabályozott térhasználat jellemezte. Gyöngyi napi útvonalai gyerekként és fiatal lányként is meglehetősen szabályozottak voltak. Gyerekként a szüleivel járt néha vásárokba, de egyedül nem igazán mehetett sehová, a falubeli programokon is bátyja vagy barátnői kíséretében vett részt. Ilyenkor korán haza kellett

17 Bár ezt a családtörténet kontrasztokban reprezentált helyei és a narratíva íve inkább egy nagyobb ugrásnak mutatja - lásd például az első interjúrészletet.

18 Mindez visszatükrözi a korábban jelzett szakirodalmi összefüggést, hogy a kétkeresős stabil munkaviszony elültetheti a „normális élet" vágyát (Kovai 2019). 
érnie, a késést szigorúan büntették a szülei. Gyöngyi mindezt a szülei féltő gondoskodásaként értelmezi, és csak kisebbrészt köti a (roma) női mivoltához, valamint az ehhez kapcsolódó elvárásokhoz: „engem akkor azért nem engedtek, mert féltettek, meg lány, meg mit tudom én, most már értem". Mindazonáltal fontos leszögezni, hogy az efféle női térhasználatra vonatkozó szabályok távolról sem kizárólag etnikai meghatározottságúak ${ }^{19}$.

Ebben a térhasználatban nagy változást hozott Gyöngyi életében a hütőház munkásbusza, amely nemcsak a faluból vitte ki Gyöngyit, hanem az otthoni térhez, a családhoz kötődő hagyományos női szerepeken is lazított. Mivel lelkesen és nagy munkabírással vetette bele magát a munkába, a csarnokban még "férfimunkára” is beosztották. E határátlépések ellenére ugyanakkor úgy tünik, hogy a faluban és az otthoni térben változatlanul a hagyományos szerepek között élt, amiből nehéz volt kiszakadnia. A férjével is úgy ismerkedett meg, hogy közel húszéves dolgozó nőként volt „tárgyalási alapja” apja szigorú szabályaival szemben, és mind a fizetett, mind az otthon elvégzett munkájára hivatkozhatott:

„[...] mert már szerettem volna kicsit eljárni otthonról, vagy nem egész nap otthon ücsörögni, és végül is ott ismerkedtünk meg. És akkor onnét kezdve... nehéz volt, mert tényleg nem öhm mehettünk onnét sehová, öhm a találkánk akkor mindig nagyon körülményes volt. [nevet] De akkor én dolgoztam, és azzal tudtam érvelni, hogy öhm dolgozom, hazaérek, megcsinálok otthon mindent, takarítás, bármi, amit még kell még délután, csak egy kicsit hadd mehessek el otthonról. És így, igen."

A városba költözve Gyöngyi idősgondozói munkája felülírta a tradicionális nemi szerepekhez köthető, szabályozott térhasználatot. A korábbi kötött útvonalaihoz képest nagy változás, hogy maga tervezi a tömegközlekedési útvonalait, maga osztja be idejét, mivel segítségre szoruló időseket látogat az otthonukban. Bejáratos idegen, más státuszú idősek otthonába, ami nyilvánvalóan hat érték- és ízlésorientációira, illetve az önképére is, hiszen bizalmat élvező, kompetens segítőként jelenik meg. Jóllehet a gondozói munka - tartalmát tekintve - továbbra is kötődik a hagyományos nemi szerepekhez, Gyöngyi számára mégis a közalkalmazotti lét a társadalmi mobilitás, az előrelépés terepe és szimbóluma ${ }^{20}$. Nemcsak minimális anyagi biztonságot nyújt neki és családjának, hanem közvetíti a társadalmi hasznosság, a munkahelyi megbecsültség és bizonyos fokig a társadalmi felemelkedés tapasztalatát is. Mindez merőben más társadalmi pozíciót és tapasztalatokat körvonalaz, mint a korábbi falusi pozíciója, ahol a roma származását a stigmatizáció miatt megpróbálta elrejteni (Wacquant 2011; Wacquant-Slater-Pereira 2014). A városi tér személytelensége és

19 Czibere Ibolya (2012) szerint az alacsony státusú, szegény férfiak is elvárják, hogy a nők otthonukhoz kötötten éljenek, a külső kapcsolataikat minimálisra szorítsák, ezáltal is ellenőrizhetőek legyenek akár szexuális értelemben, akár a munkateljesítmény, az elvégzett házimunka terén. Mindezek miatt is épül be a tradicionális (szegény) női szerepbe a tủrés, a türelem, a fáradhatatlan munkavégzés, a szorgalom.

20 Váradi Monika tanulmányában (2015) egy vidéki település felzárkóztató intézményeiben foglalkoztatott nők szakmai életútját vizsgálva rámutat arra, hogy milyen rétegzetten vannak jelen a projektvilágba bekerülő roma nők élettörténetében, önképében a roma/cigány identitás elemei és az elismerés igénye. Ezek finom kölcsönhatásai, a társadalmi hasznosságban, a helyi közösségek által mintának tekintett szerepben, a kiemelkedés és ágencia élményében, valamint a női szerepek megváltozásában egyaránt tetten érhetők. Hasonlóan összetett folyamatokat regisztrál a roma nők mobilitása, munka- és családkoncepciói terén Durst Judit, Fejős Anna és Nyírő Zsanna (Durst-Fejős-Nyírő 2016; Durst-Nyírő 2018b). 
az idősgondozással megváltozott társadalmi szerep viszont megteremti a roma identitás vállalásának a lehetőségét ${ }^{21}$.

A térhasználat átalakulása jelentős változásokat jelez mind az értékorientációkban, mind az életmódban. Gyöngyi munkavállalásának alapvető feltétele a kiegyensúlyozott párkapcsolat, jóllehet a térhasználat és vele a nemi szerepek átalakulását a bérmunka világa mozgatja. Ugyanakkor a két kereset nélkül a család városi otthona, a megszerzett térbeli-társadalmi pozíciója fenntarthatatlan lenne. Ez olyan mélyen beépült Gyöngyi habitusába, hogy korábbi és mostani lakóhelyét is sokszor a munkalehetőségek, az ingázás és a távolságok szűrőjén nézi és értékeli.

A térhasználat változásaiból a habitus dinamikája, az adaptáció lehetősége és ennek korlátai is kiolvashatók. A habitusnak van egyfajta önvédelmi funkciója, amely a szocializáció során bevésett (rutin)cselekvésekhez nem illeszkedő, szokatlan helyzetek elkerülésén, illetve az ismert helyzetek preferálásán alapul (Fáber 2018). Ugyanakkor a habitusnak van valamiféle improvizatorikus, új gyakorlatokat generáló potenciálja is (Bourdieu 2000, 2002; Fáber 2018). Ezek kölcsönhatására világít rá az, hogy Gyöngyi még a falusi „cigánysoron” megszerzi a vágyott jogosítványt. A későbbi otthon helyszínére, a szóban forgó városba járt vezetni úgy, hogy gyakorlatilag nem ismerte a teret. Ebből a váratlan, a marginalizált térhez és pozícióhoz nem illeszkedő vállalásból jól látszanak a fiatal pár mikromobilitással változó orientációi és ambíciói. Ugyanakkor Gyöngyi azóta sem igazán vezet. Bár már kiismeri magát a városban, mégsem szereti, ha egy nap sokat kell a városon belül buszoznia, mert a begyakorolt útvonalakon kívül néha még elbizonytalanodik a városi térben. A közeli nagyobb városba sem szívesen utazik egyedül.

\section{Az elért pozíció szubjektív értékelése - önpozicionalizálás és „társadalmi helyérzet”}

A szóban forgó város zsugorodása és ennek térbeli-társadalmi hatásai egy olyan átmeneti térben csapódtak le, amely egyszerre lehet a megkapaszkodás vagy a lecsúszás, a bennragadás tere. Talán épp az átmenetiségből fakadó ambivalenciái és társadalmi nyitottsága teszi ezt a lakótelepet Gyöngyi számára igazán otthonossá: „Tehát más városrészben nem biztos, hogy én olyan jól érezném magam, mint itt."

A városi téren túl azonban a család társadalmi pozíciójában, illetve az ahhoz való viszonyukban is ambivalencia rejlik. Gyöngyi elbeszéléséből kibomlik, hogy mit jelent számukra a városba költözés és az azzal járó életmódváltás (szubjektív mobilitás - Huszár-Záhonyi 2018). Emellett az is kiderül, hogy mit gondolnak arról, hogyan nézhet ki a pozíciójuk kívülről, mások szemével. Gyöngyi ezért az interjúk alatt folytonosan pozicionalizálta magát és a családját. Mindez arról informál, hogyan érzik magukat az új térben, egyszersmind az elért társadalmi pozíciójukban, azaz milyen a „társa-

21 A kérdéshez lásd bővebben: Kovai 2017. 
dalmi helyérzetük" (Hillier-Rooksby 2002). Gyöngyi sokszor puhította, relativizálta az interjúban elhangzottakat, reflektálva arra, hogy mindaz, amit elértek, számukra nagy lépés, de mások szemében talán nem is akkora eredmény. (A megszerzett lakás „valami álom”. Majd rögtön hozzátette: „Most, ahhoz képest.”) Mondandójának sajátos ritmust, dinamikát kölcsönzött az állítás, majd annak relativizálása, megkérdőjelezése, ami azt sugallja, hogy kívülről is szemügyre veszi és értelmezi a megélt élményeit.

A „társadalmi helyérzethez” kötődő ambivalencia mind az otthonra, mind a munkára vonatkoztatva megjelenik Gyöngyi történetében. A szeretett lakótelepi lakásukat például így jellemzi: „ez a mi kis rezidenciánk. De szeretem. Jó.” A „kis rezidencia” kifejezésben bujkáló ambivalencia valamifajta öniróniát sejtet, ami arra utalhat, hogy nekik ez az otthon önmagában nagy eredmény, de kívül „csak” egy hitelre megvásárolt lakótelepi lakás. Egyfelől büszkén meséli, hogy nem minden bútort hoztak el az előző, falusi lakhelyükről, másfelől a vásárlás anyagi korlátait, azaz (ízlés)választásaik anyagi és habituális korlátait is hangsúlyozza. Ezeket az ellentmondásokat, egyszersmind a felfelé törekvés, a státuszelérés és -megtartás küzdelmeit Gyöngyi így összegzi: „ez még nem a teljes igényünk, csak így volt lehetöségünk. Most jobban még nem tudjuk, majd talán egyszer sikerül, hogy szebb meg jobb lesz.” Ez egyfelől visszatükrözi az „úton lévőséget”, a felfelé mozgásból fakadó átmenetiséget, másfelől a kiszólás sűríti azt az igyekezetet, hogy hiánytalanul betöltsék az új társadalmi pozíciót és az ehhez társított alsó (közép)osztályi életmódot, amit éppen a lakáshitel miatti anyagi megterhelés akadályoz a leginkább. (A tanodák kontextusában lásd: Kovai 2020.)

Gyöngyi a „kis” kitétel mellett szintén sokszor él az „idézőjelben” fordulattal, ami szintén relativizálásra, önreflexióra utal. Sokszor említi, hogy igyekeznek „idézőjelben mindent" megadni a gyereküknek. Ebben a kitételben éppen a minden és a számukra teljesíthető maximum feszültsége csapódik le. Mindez azt mutatja, hogy bár az otthonukat (térbeli pozíció) belakták, társadalmi pozíciójukban nem annyira biztosak és otthonosak.

Az ambivalens „társadalmi helyérzet” a foglalkozási mobilitásra is kivetül, ugyanis mindkettő egy felfelé mobil pálya átmeneti, ellentmondásokkal átszőtt tere, közege. Miközben az idősgondozás Gyöngyinek a felemelkedést jelenti, kívülről nézve ez is kissé keserübbé válik. Gyöngyi a közalkalmazotti létet az ehhez kapcsolódó szerep és társadalmi közeg miatt magasabbra értékeli, mint az előző munkáit, ugyanakkor érzi az új társadalmi pozíció körüli ellentmondásokat, köztük az anyagi korlátokat, a hierarchiát is: „[...] jelentkeztem erre, hogy én ezt szeretném csinálni, és mindig arra gondoltam, hogy jaj, istenem, fehér köpenyes [állás], meg egy kicsit öhm többnek érzem magam. Pedig igazán mi vagyunk a legalján, mert mi végzünk el minden munkát, de én ezt igazán nem is bánom, én ezt így szeretem csinálni."

A felfelé irányuló mobilitáshoz kötődő átmenetiséget egyszersmind az ambivalens „társadalmi helyérzetet” tovább erősíti, hogy míg az erősen marginalizált falusi térben felfelé „lógtak ki”, addig a társadalmilag heterogénebb átmeneti térben a megkapaszkodásért küzdenek, és hogy „ne lógjanak ki”. Az erősen stigmatizált falusi térben Gyöngyiék lakása volt a „legkiemelkedőbb” a házsoron, amelyet megpróbáltak a 
lehetőségeikhez mérten, kisebb hitel felvétele árán is komfortosítani. Náluk a védőnő is megpihent, jól érezte magát. Ugyanakkor a marginalizált házsoron kiemelkedő, a többségi társadalom elvárásainak megfelelni igyekvő család az erőfeszítéseiért a faluban már nem feltétlenül kapott elismerést.

Gyöngyi többször utal rá, hogy nem vágyik luxusra és gazdagságra, hanem „normális életvitelre”, amit a lakótelepi lakás és a városi élet biztosít számukra. A normálist úgy tünteti fel, mint a luxus és az általuk megélt szegénység közötti középutat, egy, a társadalom többsége számára elérhető életnívót, ami nekik eddig csak vágy volt, és most is csak komoly erőfeszítések árán megvalósítható. Mindezzel elhelyezi magát és családját a társadalmi térben, miközben a pozíció megtartásának nehézségei helyett az elért eredményekre összpontosít. Jóllehet valószínúleg tudattalanul, de folyamatosan reflektál a nehézségekre és az erőfeszítésekre is. A mostani térbeli-társadalmi pozícióra vonatkoztatott „elértem, de nem bánom” fordulat a családtörténetben folyamatosan jelen lévő feszültségeket, erőfeszítéseket sưríti. Talán ennek a feloldására is hangsúlyozza többször, hogy nem azért vágytak el a falusi cigánysorról, mert nekik olyan rossz lett volna ott, hanem mert „normális” életmódot szerettek volna teremteni, ami ott nem volt lehetséges. Ehhez azonban ki kellett szakadni a gyerekkori otthonból és a falusi közegből. A mobilitás kutatói perspektívából értelmezett „ára”22 a történetében ebben a formában viszont szinte fel sem merül, bár a nehézségek jól láthatók, és a családi szálak is lazultak. Gyöngyi családtörténete mégsem látszik alátámasztani Sorokin disszociációs tézisét, miszerint a felfelé mobil egyének kimondottan szenvednének a társas kapcsolatok hiányától, a jóllétüket fenyegető mentális krízisektől és devianciáktól (Andorka 1982; Hajdu-Huszár-Kristóf 2019). Jóllehet a család kilépett a falusi közegből, úgy tűnik, hogy a tagjai kimondottan élvezik a családi élet újraírt határait.

Talán a korábbi helyhez való kötődés, a származással érzett folytonosság, talán a felemelkedés megélt küzdelmei miatt eshet olyan erős tiltás alá a „nagyravágyás” és a „luxus” következetesen ismételt tilalma ${ }^{23}$. Mindezek megmutatják a habitusként „rögzült” „társadalmi helyérzetet” és azt is, hogy az új pozíció „belakása” megköveteli a habitus lassú változását (vö. Bourdieu 2000, 2002, 2009 [2000]; Hillier-Rooksby 2002). A „társadalmi helyérzet” körüli ambivalenciák voltaképpen a térbeli-társadalmi mobilitás megélt jelentései, amelyek az előző és a jelenlegi pozícióhoz kötött tapasztalatok, vágyak és lehetőségek összebékítésére tett erőfeszítéseket mutatják. A diszkurzív önpozicionalizálás végső soron betekintést nyújt a habitus lassú adaptálódásának folyamatába, rámutatva arra, hogy miként válik „a habitus a szükségből faragott erénnyé" (Bourdieu 2000: 143). Preferenciáinkon, választásainkon, esélylatolgatásainkon keresztül ugyanis „hajlamosak vagyunk elutasítani az amúgy is lehetetlent,

22 Lásd erről bővebben: Durst-Fejős-Nyírő 2016, Durst-Nyírő 2018b.

23 A kiemelkedést, kifelé vágyódást tiltó vagy rosszalló közösségi ellenőrzésre példa az uradalmi pusztai lét kontextusában, hogy a jobb munka- és életfeltételeket kereső, puszták között költözködő „megelégedetleneket” (Németh 2013: 45) enyhe rosszallás övezte; miközben a helyben maradásnak nagyobb presztízse volt. A kiemelkedés és a megkülönböződés igényét és árnyalatait a cigány közösségek is figyelemmel kísérik, lásd például a „kényesek” és a „piszkosak" közötti különbségtételt (Kovai 2017). 
illetve előnyben részesíteni az amúgy is elkerülhetetlent” (Bourdieu 2009 [2000]: 211). Gyöngyi történetében különös téttel bír az, hogy a különféle terekhez kötődő diszpozíciók között közvetítsen. Ez megfigyelhető azon diszkurzív erőfeszítésében, hogy az elhagyott otthona ne kizárólag negatívként, értéktelenként reprezentálódjon a történetében, és hogy a múltjával, származásával is folytonosságot teremtsen. A vágyak és a lehetőségek mederben tartásával ugyanakkor csökkenti a „társadalmi helyérzet" körüli ambivalenciákat. Ezt mutatja az új otthon körüli átmeneti tér bizonyos ambivalenciáinak kizárása, az azonosulás a gondozói munkához kötődő új társadalmi szereppel, ami megköveteli az új térhasználati minták habitusba építését, és ezt jelzi végső soron a mobilitás értelmének keresése, az önpozicionalizálás.

A korábbi marginalizált térhez való kötődést, illetve a kilépés objektív és szubjektív nehézségeit sűríti a következő fordulat: „szerettünk volna kicsit kitörni”. A kicsit kitételben benne van a fent elemzett mikromobilitás (Németh 2020; Porcelli et al. 2014) fokozatossága és óvatossága, mivel a kifejezés már rögtön puhítja és relativizálja az elhatározás súlyát. A kifejezés mintha éppen a vágy és a realitás ellentétét próbálná összesimítani, miközben feltehetően a nagyravágyás közösségi tilalma miatt is nehezebb volt a kitörés. Ezért is bírhatott katalizátorhatással a mikromobilitás, ami első lépésben a rokoni és társas támogatással, erőforrásokkal átszőtt térben ültette el a mobilitás szándékát. Ezt viszont bizonytalanság övezte. Gyöngyi többször hangsúlyozta, hogy úgy érezték, gyorsan kell cselekedniük, amíg a párjának van munkája. De a szinte folyamatos munkaviszonyuk ellenére sem volt könnyú hitelt szerezniük, így ez a lakás volt a legtöbb, amit a kapott hitelből ki tudtak hozni. Mindez a felemelkedés általános esélyeivel egyszersmind a kínálkozó lehetőségek átmenetiségével való előzetes számvetést is jelzi, de benne lehet a devizában felvett lakáshitel és a 2008-as válság sokkja, utólagosan leszűrt tapasztalata is (vö. Czirfusz et al. 2019; CsizmadyHegedüs-Vonnák 2019; Csizmady-Kőszeghy-Győri 2019).

A család kitörésében a falu taszító tényezői is szerepet játszottak. Mindazonáltal a „kitörésük” inkább fokozatos kiemelkedés volt, amit a mikromobilitás gyorsított fel. Mobilitásuk azt mutatja meg, hogy milyen nehéz bérlőből tulajdonossá válni egy marginalizált, erőforráshiányos helyzetben és mekkora erőfeszítés egy szegregált térből kijutni a család anyagi támogatása nélkül (vö. Csizmady-Hegedüs-Vonnák 2019; Csizmady-Kőszeghy-Győri 2019). A kiemelkedésükben tágabb makrostrukturális, társadalmi és gazdasági hatások, intézményi folyamatok is látszanak, mindenekelőtt a lakáspolitikai támogatás igénybevétele, a devizahitel elérhetősége egy gazdaságilag prosperáló szakaszban ${ }^{24}$. A történetből kiolvashatók az otthonnak választott átmeneti tér sajátos ambivalenciái, a vonzereje és megtartásának nehézségei is csakúgy, mint a devizahitel-felvétel és az ebből fakadó nehézségek, illetve a marginalizált réte-

24 Gyöngyiék devizahitel-felvétele és lakásvásárlása a lakáshitelezés 2004 után felgyorsuló második szakaszában történt, amikor a lakosságot a forinthitelektől a kedvezőbb kamatozású és alacsony kockázatúnak vélt devizahitelek felé terelték (CsizmadyHegedüs-Vonnák 2019). 
gek felemelkedésének, előrejutásának gazdasági ciklikussága (vö. Czirfusz et al. 2019; Csizmady-Hegedüs-Vonnák 2019; Kovai 2019, 2020; Vigvári 2016)

A család mobilitási erőfeszítéseinek értékelését nem csak az interjúhelyzet stimulálja. Gyöngyi gyakran utal arra, hogy sokat beszélgetnek a múltról a gyerekükkel, akinek az ő régi világuk már idegen. Emellett folyamatosan egyeztetik a preferenciáikat és értelmezik a helyzetüket. A megnövekedett reflexiós igény jól jelzi a „társadalmi helyérzet” körüli feszültségeket (vö. Bourdieu 2000), mivel maguk is a mobilitási erőfeszítéseik értelmét keresik, és igyekeznek ezeket családilag kidolgozott történetekkel, jelentésekkel is legitimálni. Mindez folyamatos önpozicionalizálásra sarkallja őket, így nem meglepő, hogy Gyöngyi a családi döntések mögötti kényszereket és mozgástereket is élénken érzékelteti az interjúkban. A korlátozott mozgásteret a választások és kényszerek kölcsönhatásai alakítják, miközben ezek a preferenciák és a választások közvetítésével, a vágyak és lehetőségek finom egymásra hangolásával nyernek formát a habitusban „szükségből faragott erényként” (Bourdieu 2000: 143). Miközben azt figyelik, hogy mi a külső világban az észlelt „normalitás”, mérlegelik, hogy azt hogyan, milyen erőfeszítések árán tudják megvalósítani. Így alakul lassan a hátrahagyott életmód (meg nem tagadott és nem lenézett) szegénységgé, így lesz az elérhetőből otthonos és „normális” (és fordítva), valamint így válik az elérhetetlen felesleges luxussá (vö. Bourdieu 2000, 2002, 2009 [2000]). Mindezek egyrészt segítenek értelmezni a helyzetüket, másrészt értelmet adnak a komoly áldozatvállalások árán elért térbeli-társadalmi pozíciónak. Az otthonuk fenntartása megerősíti és viszszaigazolja a mobilitási erőfeszítéseiket:

„És most itt tartunk, de... de én nem is bánom. [...] Huszonöt évre vettük fel a lakáshitelt, és öh [sóhajt] van még vissza böven, [felgyorsul] nem baj, de legalább, most én úgy gondolom, hogy egy olyan helyen vagyunk, ahol* Most, hogyha én elmennék egy albérletbe, akkor nem a sajátomat fizetném. Most talán, talán majd saját lesz egyszer, és jó lesz."

\section{Összegzés}

Gyöngyi és családja története nem egyszerűen egy falusi, telepi marginalizált térből („cigánysorról”) egy relatíve jobb helyzetű városi átmeneti térbe történő térbeli mobilitás. Mivel a szóban forgó helyek marginalizáltságának foka távolról sem azonos, így a közöttük lévő mozgás már csak emiatt is mobilitásként, sajátos tartalmú társadalmi előrelépésként értelmezhető. A szóban forgó lakótelep összetett városi jelentései, sajátos, billegő helyzete a városi térben és diskurzusban is jelzi azt, hogy inkább egy heterogén összetételű, bizonytalanabb státuszú átmeneti térbe érkeztek (vö. Vigvári 2016; Virág 2018). Ez a város zsugorodásának kontextusában egyszerre lehet a társadalmi előrelépés, a lecsúszás vagy a bennragadás tere, amelynek jövőbeli státuszát a benne élő családok pályája, sorsa is alakítja. Következésképp Gyöngyi és családja mobilitási pályája egyszerre tekinthető bizonyos fokig tipikusnak az adott városi átmeneti térben, illetve atipikusnak a falusi marginalizált térből való ritka kilépés miatt. 
A család térbeli mobilitását egy kívülrôl alig látható, ugyanazon a marginalizált téren belüli mikromobilitás (Németh 2020; Porcelli et al. 2014) katalizálta, amely erősen formálta a vágyakat, és megerősítette a kétkeresős bérmunkán, hitelfelvételeken keresztüli kitörés aspirációját (Kovai 2019). Hasonló fokozatos előrelépés mutatkozik Gyöngyi foglalkozási mobilitásában is. A marginalizált falusi térből való fokozatos kiágyazódás, a házasság és legfőképp az idősgondozói munkával megváltozott társadalmi szerep és rutin átalakította Gyöngyi - korábban a hagyományos női szerepekhez kötődő - térhasználatát. A térbeli-társadalmi mobilitás íve a két marginalizált hely reprezentációja közötti kontrasztból és a foglalkozási mobilitásból, míg a szubjektív mobilitás megélt tartalma inkább a helyekhez kötődő térhasználat változásából, a preferenciák, az életmód átalakulásából, illetve az e körüli feszültségekből kiolvasható.

A család helyzete mindkét térben kissé ambivalensnek tünik, az elhagyott falusi marginalizált térben relatíve jobb, a városi átmeneti térben a lakáshitel terhei miatt relatíve bizonytalanabb a helyzetük. Mindez a felfelé történő térbeli-társadalmi mobilitással együtt ambivalens „társadalmi helyérzetet” körvonalaz, ami voltaképpen a habitus lassú adaptálódásaként is értelmezhető. Az ambivalenciák összebékítésére tett erőfeszítések, azaz a diszkurzív önpozicionalizálás betekintést nyújt abba, hogy miként válik „a habitus a szükségből faragott erénnyé" (Bourdieu 2000: 143). A preferenciák és választások, a vágyak és a lehetőségek finom egymásra hangolása, folyamatos megvitatása családi körben is folyik, ami számukra is segít értelmezni mobilitásukat, azaz az elért, ambivalenciáktól sem mentes térbeli és társadalmi pozíciójukat, és egyben igazolja mobilitási erőfeszítéseiket.

\footnotetext{
Abstract: This paper is an attempt to analyse the range and the lived meanings of the spatial and social mobility trajectory of a Roma woman, who moved from a marginalised and stigmatised part of a village with her family to a more socially heterogeneous urban transitory space (cf. Vigvári 2016; Virág 2018). Drawing on the conceptualisation of the habitus as „social sense of place” (Bourdieu 2002; Hillier-Rooksby 2002), the analysis tries to grasp the cognitive structures of habitus through the representation of places and the place experience, and its embodied structures through the use of space and the lifestyle (cf. Bourdieu 2000, 2002; Dúll 2014, 2015a, b). The analysis shows that this family history is not simply a spatial mobility trajectory from a marginalized rural space to a relatively better urban transitory space. In fact both, the spatial and the social (occupational) mobility imply gradual, but significant progress. This family has been gradually disembedded from a marginalised rural place; their social and spatial trajectory was catalysed by an instance of micromobility (cf. Porcelli et al. 2014). The spatial trajectory can be traced by the representation of places, while the range of the social mobility can be revealed through changes in occupational mobility. Lived meanings of this mobility can be grasped by the changes in use of space and lifestyle. The spatial trajectory was shaped by the push factors of the village, and by the pull factors of this specific urban transitory space, which has been shaped by diverse effects of urban shrinkage. Consequently, this woman's and her family's mobility trajectory can be considered to some extent as a typical mobility path in the given urban transitory space, while it is also atypical since exit opportunities from rural marginalised places are rare. Mobility is "transitory" because it inherently includes movement: this family did not really fit neither the rural nor the urban place. Therefore their upward spatial and social mobility comes with an ambivalent "social sense of place". All these lived meanings of this ambivalence trigger a self-positioning, but it is also reflected in the gradual changes in their habitus.
}

Keywords: spatial and social mobility, habitus, social sense of place, representation of place, use of space 


\section{Irodalom}

A. Gergely A. (2007): Felvezetés. In A. Gergely A. - Bali J. (szerk.): Város-képzetek. Az antropológiai megismerés árnyalatai. Budapest: Könyv Kiadó - MTA PTI Etnoregionális Kutatóközpont - ELTE BTK Néprajzi Intézet, 5-9.

Andorka R. (1982): A társadalmi mobilitás változásai Magyarországon. Budapest: Gondolat Kiadó.

Berger V. (2018): Térré szôtt társadalmiság. Budapest: L’Harmattan Kiadó.

Biczó G. (2018): A hely fogalma, jelentése és reprezentációja a 70-es évek szociográfiájában. In Tóth P. P. (szerk.): A magyar szociográfia a 20-21. században. (Magyarország felfedezése). Budapest: Gondolat Kiadó, 45-57.

Bourdieu, P. (2000): Bodily Knowledge. In uő.: Pascalian Meditations. California: Stanford University Press, 128-164.

Bourdieu, P. (2002): Habitus. In Hillier J. - Rooksby E. (eds.): Habitus: A Sense of Place. Aldershot-Burlington: Ashgate, 17-37.

Bourdieu, P. (2009 [2000]): Struktúrák, habitusok és gyakorlatok. In uő.: A gyakorlat elméletének vázlata. Három kabil etnológiai tanulmány. Budapest: Napvilág Kiadó, 208-236.

Creswell, T. (2009): Place. https://booksite.elsevier.com/brochures/hugy/ SampleContent/Place.pdf Utolsó letöltés: 2020. 05. 19.

Czibere I. (2012): Nók mélyszegénységben. Budapest: L’Harmattan Kiadó.

Czirfusz M. - Ivanics Zs. - Kovai C. - Meszman T. T. (2019): A magyarországi munkásság a hosszú lejtmenetben. Fordulat [2008-2018: Válság és hegemónia Magyarországon], 26(2): 142-172.

Csizmady A. - Hegedüs J. - Vonnák D. (2019): Lakásrezsim és a devizahitel-válság: intézményi és egyéni stratégiák. Szociológiai Szemle, 29(2): 4-32.

Csizmady A. - Kőszeghy L. - Győri Á. (2019): Lakásmobilitás, társadalmi pozíciók és integrációs csoportok. socio.hu, 9(2): 1-27. DOI: 10.18030/socio.hu.2019.3.1

Dúll A. (2014): Térrétegek kívül-belül: az ember és a földrajzi tér kapcsolata In Dúll A. - Izsák É. (szerk.): Tér-rétegek. Tanulmányok a XXI. század térfordulatairól. Budapest: L'Harmattan Kiadó, 7-13.

Dúll A. (2015a): Az identitás környezetpszichológiai értelmezése: helyérzés, helykötődés és helyidentitás. In Bodor P. (szerk.): Emlékezés, identitás, diszkurzus. Budapest: L'Harmattan Kiadó, 79-99.

Dúll A. (2015b): Amikor messze van az „odakinn” az „idebenn”-től: a helyváltoztatás és az identitás összefüggései. In Keszei A. - Bögre Zs. (szerk.): Hely, identitás, emlékezet. Budapest: L’Harmattan Kiadó, 19-33.

Durst J. - Fejős A. - Nyírő Zs. (2016): Másoknak ez munka, nekem szívügyem”. Az etnicitás szerepe a diplomás roma nők munka-család konstrukcióinak alakulásában. socio.hu, 6(2): 198-225. 
Durst J. - Nyírő Zs. (2018a): Constrained choices, enhanced aspirations: Transnational mobility, poverty and development. A case study from North Hungary. Review of Sociology of the Hungarian Sociological Association, 28(4): 4-36.

Durst J. - Nyírő Zs. (2018b): Soul work and giving back. Ethnic Support Groups and the Hidden Costs of Social Mobility. Intersections East European Journal of Society and Politics, 4(1): 88-108. DOI: 10.17356/ieejsp.v4i1.406

Fáber Á. (2018): A habitus. In Pierre Bourdieu: Elmélet és politika. Budapest: Napvilág Kiadó, 53-64.

Goffman, E. (1981): A hétköznapi élet szociálpszichológiája. Budapest: Gondolat.

Hajdu G. - Huszár Á. - Kristóf L. (2019): Mobilitás és társadalmi integráció. socio.hu, 9(4): 42-61. DOI: 10.18030/socio.hu.2019.4.42

Hidas Z. (2015): Helyek, emlékek, identitások - belakott világaink. In Keszei A. - Bögre Zs. (szerk.): Hely, identitás, emlékezet. Budapest: L’Harmattan Kiadó, 34-51.

Hillier, J. - Rooksby E. (2002): Introduction. In Hillier J. - Rooksby E. (eds.): Habitus: A Sense of Place. Aldershot-Burlington: Ashgate, 3-27.

Huszár Á. - Záhonyi M. (2018): A szubjektív mobilitás változása Magyarországon. Demográfia, 61(1): 5-27. DOI: 10.21543/Dem.61.1.1

Jelinek Cs. (2020): „Gúzsba kötve táncolunk”. Zsugorodás és a kontroll leszivárgásának a politikai gazdaságtana magyarországi középvárosokban. Szociológiai Szemle, 30(2): 115-136.

Kende A. - Illés A. (2011): Hátrányos helyzetű gyerekek jelen- és jövőképe. „Erős fal, kerítés, nagy kutya, állás a rendőrségnél”. Esély, 22(4): 72-92.

Keszei A. (2015): Hely és emlékezet között In Keszei A. - Bögre Zs. (szerk.): Hely, identitás, emlékezet. Budapest: L’ Harmattan Kiadó, 52-73.

Kollár Á. - Tamáska M. (2019): Genius loci: egy módszertani fogalom. In Tamáska M. - Kollár Á. (szerk.): Genius loci. Irodalom és építészet. Budapest: Martin-Opitz Kiadó, 7-13.

Koós B. (2020): Városi zsugorodás és lakóhelyi szegregáció Magyarországon. Tér és Társadalom, 34(1): 48-68.

Kovács É. (2006): Mari és az ő „cigánysága” - avagy a narratíva helye és ereje az etnicitás kutatásában. Tabula, 9(1): 41-52.

Kovács É. (2007a): Interjús módszerek és technikák. In Kovács É. (szerk.): Közösségtanulmány. Módszertani jegyzet. Budapest: Néprajzi Múzeum - PTE BTK Kommunikáció- és Médiatudományi Tanszék, 269-278.

Kovács É. (2007b): Narratív biográfiai elemzés. In Kovács É. (szerk.): Közösségtanulmány. Módszertani jegyzet. Budapest: Néprajzi Múzeum - PTE BTK Kommunikáció- és Médiatudományi Tanszék, 373-396.

Kovács É. - Vajda J. (2002): Mutatkozás. Zsidó identitástörténetek. Budapest: Múlt és Jövő.

Kovai C. (2017): A cigány-magyar különbségtétel és a rokonság. Budapest: L’Harmattan Kiadó. 
Kovai, C. (2019): Permanent wage labour as a norm. Workfare policy and everyday experiences of precariousness in a small Hungarian former industrial town. socio. hu, 9(7): 143-161. DOI: 10.18030/socio.hu.2019en.142

Kovai C. (2020): Egy „elképzelt” középosztály és a lokalitás „valósága”: tanoda programok mozgásterei egy zsugorodó városban. Szociológiai Szemle, 30(2): 72-95.

N. Kovács T. (2019): Bányák és lakótelepek. Pécs-Uránváros egy szociográfia tükrében. In Tamáska M. - Kollár Á. (szerk.): Genius loci. Irodalom és építészet. Budapest: Martin-Opitz Kiadó, 157-175.

Németh K. (2013): „Koszos lóra bársony nyereg nem illik”. Cselédek és urak - egykor és most. Belvedere Meridionale, 25(3): 31-50.

Németh K. (2020): „Cseberből vederbe” - A mikromobilitás mintázatai egy marginalizált mikrotérben. Tér és Társadalom, 34(3): 90-113. DOI: 10.17649/ TET.34.3.3279

Pintér J. N. (2012): A tudattalan identitás. Imago, 2(2): 67-72.

Porcelli, P. - Ungar, M. - Liebenberg, L. -Trépanier, N. (2014): (Micro)mobility, disability and resilience: exploringwell-being amongyouth with physicaldisabilities. Disability \& Society, 29(6): 863-876. DOI: 10.1080/09687599.2014.902360

Shank, G. (2008): Abduction. In Given, L. M. (ed.): The SAGE Encyclopedia of Qualitative Research Methods, Vol. 1-2. Los Angeles - London - New Delhi - Singapore: SAGE $1-2$.

Váradi M. M. (2015): Roma nők a projektvilágban: portrék. In Virág T. (szerk.): Törésvonalak. Szegénység és etnicitás vidéki terekben. Budapest: Argumentum, 121-141.

Vigvári, A. (2016): 'Rural poverty' in urban spaces of Budapest Research proposal for examining spatial inequality in contemporary Hungary. socio.hu, 6(4): 47-61.

Virág, T. (2018): Spatial Marginalization of Roma in Bulgaria and Hungary. CAS Sofia Working Paper Series, 10. Sofia: Centre for Advanced Study (CAS), 1-31.

Virág T. (2019): A kapcsolathálózatok szerepe a migrációban egy cigányfalu perspektívájából In Váradi M. M. (szerk.): Migráció alulnézetból. Budapest: Argumentum, 74-94.

Virág T. (2020): Demográfiai polarizáció, térbeli és társadalmi marginalizáció két zsugorodó középvárosban. Szociológiai Szemle, 30(2): 27-49.

Wacquant, L. (2011): Lakóhely szerinti megbélyegzés a fejlett marginalitás korában. Fordulat, 13(1): 14-27.

Wacquant, L. - Slater, T. - Pereira, V. B. (2014): Territorial stigmatization in action. Environment and Planning A, 46(6): 1270-1280. 